\title{
Comparison of the diagnosis of malaria by microscopy, immunochromatography and PCR in endemic areas of Venezuela
}

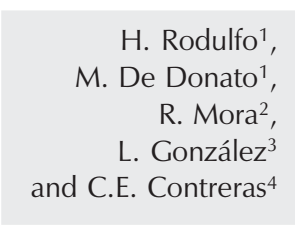

\section{Correspondence}

M. De Donato

Departamento de Biomedicina

Instituto de Investigaciones en

Biomedicina y Ciencias Aplicadas

(IIBCA), Universidad de Oriente

Cerro del Medio

Cumanás 6101

Venezuela

Fax: +58-293-452-1297

E-mail: marcosdedonato@yahoo.com

Research supported by the Fondo Nacional de Ciencia, Tecnología e Innovación (FONACIT, No. PEM-2001001621).

Received October 5, 2005 Accepted January 9, 2007

\author{
${ }^{1}$ Laboratorio de Genética Molecular, Departamento de Biomedicina, \\ Instituto de Investigaciones en Biomedicina y Ciencias Aplicadas, \\ Universidad de Oriente, Cumaná, Venezuela \\ ${ }^{2}$ Banco de Sangre, Hospital J.G. Hernández, Puerto Ayacucho, \\ Venezuela \\ ${ }^{3}$ Gerencia de Saneamiento Ambiental y Malariología, Region XI, Carúpano, \\ Venezuela \\ ${ }^{4}$ Instituto de Inmunología, Universidad Central de Venezuela, Caracas, Venezuela
}

\begin{abstract}
Whole blood samples $(\mathrm{N}=295)$ were obtained from different locations in Amazonas and Sucre States, in Venezuela. Malaria was diagnosed by microscopy, OptiMAL ${ }^{\mathrm{TM}}$ and polymerase chain reaction (PCR), with Plasmodium vivax, P. falciparum, and P. malariae being detected when possible. We identified 93 infections, 66 of which were caused by $P$. vivax, 26 by $P$. falciparum, and 1 was a mixed infection. No infection caused by $P$. malariae was detected. The sensitivity and specificity of each diagnostic method were high: 95.7 and $97.9 \%$ for microscopy, 87.0 and $97.9 \%$ for OptiMAL, and 98.0 and $100 \%$ for PCR, respectively. Most samples (72.2\%) showed more than 5000 parasites/ $\mu \mathrm{L}$ blood. The sensitivity of the diagnosis by microscopy and OptiMAL decreased with lower parasitemia. All samples showing disagreement among the methods were reevaluated, but the first result was used for the calculations. Parasites were detected in the 6 false-negative samples by microscopy after the second examination. The mixed infection was only detected by PCR, while the other methods diagnosed it as $P$. falciparum (microscopy) or $P$. vivax (OptiMAL) infection. Most of the false results obtained with the OptiMAL strip were related to the $P$. falciparum-specific band, including 3 species misdiagnoses, which could be related to the test itself or to genetic variation of the Venezuelan strains. The use of the microscopic method for malaria detection is recommended for its low cost but is very difficult to implement in large scale, population-based studies; thus, we report here more efficient methods suitable for this purpose.
\end{abstract}

Key words

- Malaria

- Molecular diagnosis of malaria

- Microscopic diagnosis

of malaria

- Polymerase chain reaction

- OptiMAL 


\section{Introduction}

Malaria is the most important human parasitic disease throughout the tropical and subtropical regions of the world due to is high prevalence and mortality rate. In Venezuela, malaria is also a great concern, with 46,244 cases being reported in 2004, mainly from Sucre (10.26\%), Bolivar $(59.63 \%)$, and Amazonas (23.18\%) States (1). Detailed knowledge of the incidence and transmission dynamics of the Plasmodium species in our region is the key to design effective measures for malaria control and the treatment schemes to be used. Medical and microscopic diagnoses are universally used for the collection of epidemiological data. The standard microscopic diagnosis of malaria requires a relatively short time when the parasites are present in high numbers $(\geq 1000$ parasites $/ \mu \mathrm{L}$ ), but if parasitemia is very low, more than $10 \mathrm{~min}$ are needed to examine each slide, which is often the case in endemic areas for malaria or when drugs are taken inappropriately (2).

On the other hand, the immunodiagnostic tests used for the detection of Plasmodium are easy to use and can produce fast results, but they usually have lower sensitivity and specificity than conventional microscopic examination. Many of them have been designed to specifically detect $P$. falciparum and some of them can detect the other malaria species non-specifically. Among the most common immunodiagnostic tests available are the Parasight F-test (Becton-Dickinson Advanced Diagnosis, Franklin Lakes, NJ, USA) which detects $P$. falciparum specifically using an IgG1 monoclonal antibody that recognizes the parasite histidinerich protein 2 (3); the ICT Malaria $\mathrm{Pf} / \mathrm{Pv}$ (AMRAD, Frenchs Forest, New South Wales, Australia) and its new version NOW ICT Malaria Pf/Pv (Binax, Inc., Portland, ME, USA), which work according to the same principle but use an IgM monoclonal antibody specific for P. falciparum as well as an antibody against the Plasmodium aldolase (4), and OptiMAL (DiaMed, under license from Flow, Inc., Portland, OR, USA) which is based on the detection of the parasite lactate dehydrogenase, an enzyme produced only by live parasites, and not a residual metabolite such as parasite histidinerich protein 2 , which can thus detect active infection, being useful for the monitoring of antimalarial drug therapies $(5,6)$.

Finally, the use of molecular biology for the diagnosis of malaria has proved to be highly sensitive for the detection of the disease, but the equipment required is not widely available in many of the endemic areas and the protocol is more complex and needs better trained technicians. The use of the polymerase chain reaction (PCR), however, is extremely useful for decision making in disease control and treatment, for example, for the detection of mixed infections which play a modulatory role in the severity of the symptoms $(2,7,8)$. The greatest advantage, however, is the ability of PCR to detect infections with parasitemia as low as 5 parasites/ $\mu \mathrm{L}$ blood $(9,10)$. However, there are some problems with false-negative results when the DNA isolation protocol is not appropriate $(5,11)$; for example, not removing the inhibitors from the sample and not preventing the action of enzymes that degrade DNA.

Due to the increase of malaria cases in the last years in the regions of Venezuela where malaria is endemic, we decided to carry out a study to evaluate three different diagnostic methods applied to individuals from Sucre and Amazonas States, which represent the extremes of the Southeastern endemic region of the country, with the highest prevalence values in Venezuela, after Bolivar State.

\section{Material and Methods}

We evaluated three diagnostic methods for the detection of malaria infections. A 
total of 295 samples were analyzed, 14 of which came from Cumaná, 41 from Yaguaraparo, 100 from Cangua in Sucre State, a $P$. vivax endemic area, 17 from Puerto Ayacucho, 110 from San Fernando de Atabapo, and 13 from Santa Barbara in Amazonas State, a $P$. vivax/P. falciparum endemic area (Figure 1). Samples from Cangua, San Fernando de Atabapo, and Santa Barbara were taken at random from individuals living in those communities; the rest of the samples were obtained by active searches for positive samples at different places, except for the samples from Cumaná, which were from blood bank donors known to be free of malaria infection and were used as negative controls. Blood samples were taken intravenously from symptomatic and asymptomatic individuals of both genders and different age groups, who agreed to participate in this study by signing a consent form, and who received an immediate diagnostic result (both microscopic and OptiMAL tests) and the corresponding treatment. Samples to be used for PCR were stored frozen with EDTA at $-20^{\circ} \mathrm{C}$ until use. Two drops of blood were also taken from the ear to prepare thick and thin smears for microscopic diagnosis after standard Giemsa staining, by analyzing the slides under a 100X objective. Samples with no visible parasites after scoring 100 fields were considered to be negative for this test. Parasitemia (parasites $/ \mu \mathrm{L}$ ) was determined by counting the number of parasites present in the thick blood smear in relation to 500 white blood cells and using 8000 white cells per $\mu \mathrm{L}$ of blood (5) as a reference.

Additionally, an immunochromatographic diagnosis was carried out using the OptiMAL ${ }^{\circledR}$ strip (Flow Inc., Portland, OR, USA) according to manufacturer instructions. This test is based on a membrane coated with monoclonal antibodies specific for parasite lactate dehydrogenase, an enzyme produced by metabolizing malaria parasites. Briefly, a drop of blood is added to a well of a microtiter plate previously hydrated with buffer. A nitrocellulose strip is placed in the well, and the blood is drawn up by capillary action. After the blood is taken up completely (about $10 \mathrm{~min}$ ), the strip is transferred to the next well with buffer and allowed to clear. The test contains a positive

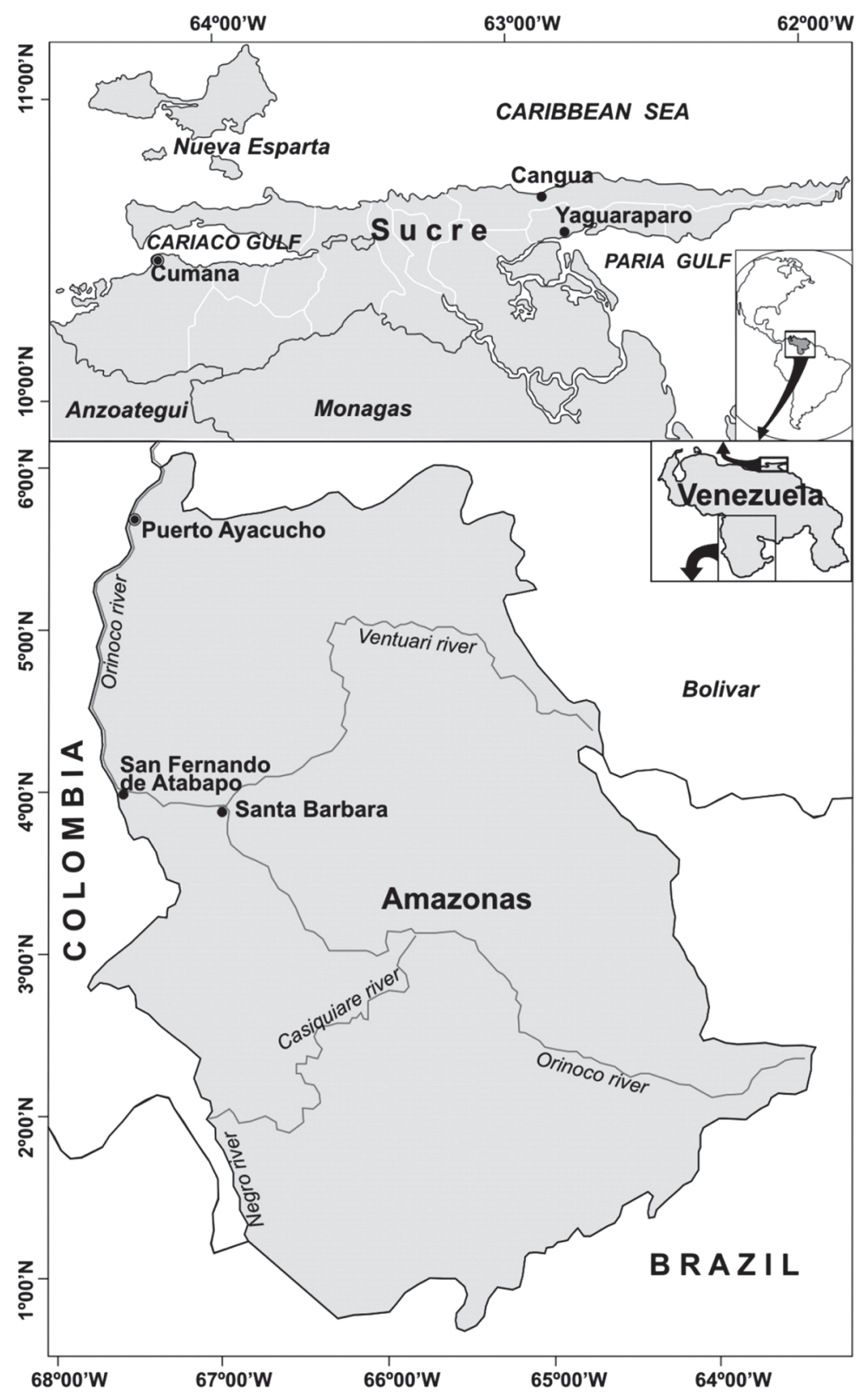

Figure 1. Localization of the populations of Sucre and Amazonas States, Venezuela, where the samples were obtained. 
control line that should be present at the top of the strip to demonstrate that it is functional. A second line, adjacent to the positive control line, indicates the presence of a Plasmodium parasite ( $P$. falciparum, $P$. vivax, $P$. ovalae, or P. malariae). A third line indicates a positive infection with $P$. falciparum, containing specific antigens.

Finally, molecular biology diagnosis was carried out using the amplification of the 18S rRNA genes with primers specific for $P$. falciparum, $P$. vivax, and $P$. malariae (2). For this, total genomic DNA was extracted from blood samples using the Wizard Genomic DNA extraction kit (Promega Corp., Madison, WI, USA) according to manufacturer instructions. Briefly, $150 \mu \mathrm{L}$ of blood was mixed with $450 \mu \mathrm{L}$ of cell lysis solution and incubated for $10 \mathrm{~min}$ at room temperature. The white blood cells and parasites were isolated by centrifugation and then mixed with $150 \mu \mathrm{L}$ nucleus lysis solution. Fifty microliters of protein precipitation solution was added and vortexed for $20 \mathrm{~s}$. The protein pellet was eliminated by centrifugation and the DNA was precipitated with isopropanol, washed with $70 \%$ ethanol and then dried and hydrated with Tris-EDTA buffer. We used a DNA sample from a patient from Yaguaraparo as the PCR-positive control for the amplification of the P. vivax fragment, as well as DNA from the cultured strain FCB (Instituto de Inmunología, Universidad Central de Venezuela, Caracas, Venezuela) of $P$. falciparum as the PCRpositive control for the amplification of this species fragment.

Amplification was done in a $25-\mu \mathrm{L}$ volume using Taq polymerase buffer $(10 \mathrm{mM}$ Tris- $\mathrm{HCl}, \mathrm{pH} 9.0,50 \mathrm{mM} \mathrm{KCl}, 0.1 \%$ Triton X100), $200 \mu \mathrm{M}$ of each dNTP, $0.75 \mathrm{U}$ Taq polymerase (Promega Corp.), either $1 \mathrm{mM}$ $\mathrm{MgCl}_{2}$ (for $P$. vivax) or $3 \mathrm{mM} \mathrm{MgCl}$ (for $P$. falciparum and $P$. malariae) and $2 \mu \mathrm{L}$ of diluted DNA (about $100 \mathrm{ng}$ ). PCR was performed individually for each species using the previously published oligonucleotides at a concentration of $175 \mathrm{nM}$. The program used for the amplification included a modification of the original program (2), with the first 10 cycles containing one step of denaturation at $94^{\circ} \mathrm{C}$ for $1 \mathrm{~min}$, one step of annealing at $54^{\circ} \mathrm{C}$ for $2 \mathrm{~min}$ and one step of polymerization at $72^{\circ} \mathrm{C}$ for $2 \mathrm{~min}$. Next, 35 cycles were used with denaturation at $94^{\circ} \mathrm{C}$ for $45 \mathrm{~s}$, annealing at $56^{\circ} \mathrm{C}$ for $90 \mathrm{~s}$ and polymerization at $72^{\circ} \mathrm{C}$ for 1 min. A final extension at $72^{\circ} \mathrm{C}$ for $10 \mathrm{~min}$ was then carried out. This modification improved the intensity of the signal while decreasing the background noise of the amplification.

Because no method was used as a gold standard, the sensitivity and specificity of each test were estimated indirectly using maximum likelihood calculations, obtained by Newton-Raphson and Expectation-Maximization algorithms available in the Webbased software TAGS (http:/www.epi.ucdavis. edu/diagnostictests/tags.html), which was designed for the evaluation of test accuracy in the absence of a gold standard (12). To run this program, the total number of individuals was divided into three populations: individuals with unknown infection status (Cangua, San Fernando de Atabapo, and Santa Barbara), those known to be infected and those known to be uninfected. The estimates of the prevalences used for input in the software were those calculated with the actual data and the estimates of the sensitivities and specificities of each method were the diagnostic agreements calculated as sensitivities and specificities using the true-positive and negative results. True results were identified by the agreement of all three methods, since the false-negative and positive results were found to be in agreement with the other two diagnostic tests after a second test/examination of all three methods. Mixed infections were scored as two separate infections to facilitate the calculations, and the misdiagnoses were considered to be false-negative results since treatment for the wrong species will not eliminate the infection due to the differences in parasite resistance (13). 


\section{Results}

We detected 93 cases of true malaria infection among the 295 samples evaluated, 66 of which were caused by $P$. vivax, 26 by $P$. falciparum and one was caused by both species. In the population-based study carried out in Sucre, there was a prevalence of $2 \%$ for $P$. vivax infection and no cases of $P$. falciparum or $P$. malariae, as expected from previous reports. In the population-based study carried out in Amazonas, the prevalences of $12.2 \%$ for $P$. vivax and $15.4 \%$ for $P$. falciparum infection were detected. No infection caused by $P$. malariae was detected by PCR or microscopy.

The microscopic diagnosis for malaria showed a high sensitivity (95.7\%) but somewhat lower than for PCR (98.0\%), and both higher than for OptiMAL (87.0\%), with these differences being statistically significant (Table 1). Specificity values were high $(\geq 98 \%)$ for all methods either for speciesspecific or nonspecific diagnosis.

When comparing the microscopic and PCR methods, there was agreement in the diagnosis of 85 positive and 199 negative samples (Table 2). Two samples were positive for $P$. vivax by microscopy and negative by PCR. Of these, one was a true-positive for microscopy undetected by PCR, and one was a false-positive for microscopy. Similarly, three samples were positive for $P$. falciparum by microscopy and negative by PCR. Of these, 1 was a true-positive for microscopy which went undetected by PCR, and 2 were false-positives for microscopy. The 2 false-negative results obtained by PCR were reanalyzed (new DNA extraction and amplification) and found to be positive. The false-positive and -negative results obtained by microscopy were rescored by a highly trained microscopist (Malaria Reference Center) who found either parasites or no sign of infection, agreeing with both the first and second PCR analysis, as well as with the OptiMAL test. Additionally, one sample
Table 1. Characteristics of the diagnostic methods for malaria in 295 blood samples.

\begin{tabular}{lcccc}
\hline Method & Positive results & Negative results & Sensitivity & Specificity \\
\hline Malaria & & & & \\
$\quad$ Microscopy & 91 & 205 & 95.7 & 97.9 \\
OptiMAL & 83 & 213 & 87.0 & 97.9 \\
PCR & 92 & 204 & 98.0 & 100 \\
Plasmodium vivax & & & & \\
$\quad$ Microscopy & 65 & 230 & 97.1 & 99.1 \\
OptiMAL & 64 & 231 & 85.4 & 98.2 \\
PCR & 66 & 229 & 98.7 & 100 \\
Plasmodium falciparum & & & & \\
$\quad$ Microscopy & 27 & 268 & 97.0 & 99.1 \\
OptiMAL & 23 & 272 & 88.2 & 98.2 \\
PCR & 26 & 269 & 98.7 & 100 \\
\hline
\end{tabular}

Sensitivity and specificity were calculated according to the criteria stated in the Material and Methods section.

Table 2. Comparison between the microscopic and PCR diagnosis in the 295 blood samples tested in the present study.

\begin{tabular}{lrrrrr}
\hline & \multicolumn{4}{c}{ PCR } & Total \\
\cline { 2 - 5 } Microscopy & $\begin{array}{c}\text { Plasmodium } \\
\text { vivax }\end{array}$ & $\begin{array}{c}\text { Plasmodium } \\
\text { falciparum }\end{array}$ & $\begin{array}{c}\text { Mixed } \\
\text { infection }\end{array}$ & $\begin{array}{c}\text { Negative } \\
\text { results }\end{array}$ \\
\hline Plasmodium vivax & 62 & 1 & 0 & 2 & 65 \\
Plasmodium falciparum & 0 & 23 & 1 & 3 & 27 \\
Mixed infection & 0 & 0 & 0 & 0 & 0 \\
Negative results & 3 & 1 & 0 & 199 & 203 \\
Total & 65 & 25 & 1 & 204 & 295
\end{tabular}

All PCR results were true results except for 1 false-negative result for Plasmodium vivax and 1 for $P$. falciparum.

Table 3. Comparison between the OptiMAL and PCR diagnosis in the 295 blood samples from this study.

\begin{tabular}{lcccrrr}
\hline & \multicolumn{5}{c}{ PCR } & Total \\
\cline { 2 - 5 } OptiMAL & $\begin{array}{c}\text { Plasmodium } \\
\text { vivax }\end{array}$ & $\begin{array}{c}\text { Plasmodium } \\
\text { falciparum }\end{array}$ & $\begin{array}{c}\text { Mixed } \\
\text { infection }\end{array}$ & $\begin{array}{c}\text { Negative } \\
\text { results }\end{array}$ \\
\hline Plasmodium vivax & 59 & 3 & 1 & 1 & 64 \\
Plasmodium falciparum & 1 & 18 & 0 & 4 & 23 \\
Mixed infection & 0 & 0 & 0 & 0 & 0 \\
Negative results & 5 & 4 & 0 & 199 & 208 \\
Total & 65 & 25 & 1 & 204 & 295 \\
\hline
\end{tabular}

All PCR results were true results except for 1 false-negative result for Plasmodium vivax and 1 for $P$. falciparum. 
which was originally scored as positive for $P$. vivax by microscopy was rescored as positive for $P$. falciparum (species misdiagnosis), agreeing with the PCR and OptiMAL result. Finally, 3 samples infected with $P$. vivax and one with $P$. falciparum were diagnosed as negative by microscopy. Rescoring of these samples agreed with the PCR and OptiMAL results.

When comparing the OptiMAL and PCR methods (Table 3), we found agreement in the diagnosis of 77 positive and 199 negative samples. One sample positive for $P$. vivax by OptiMAL and negative by PCR

Table 4. Comparisons between the OptiMAL and microscopic diagnosis in the 295 blood samples tested in the present study.

\begin{tabular}{lccccc}
\hline & \multicolumn{4}{c}{ Microscopy } & Total \\
\cline { 2 - 5 } OptiMAL & $\begin{array}{c}\text { Plasmodium } \\
\text { vivax }\end{array}$ & $\begin{array}{c}\text { Plasmodium } \\
\text { falciparum }\end{array}$ & $\begin{array}{c}\text { Mixed } \\
\text { infection }\end{array}$ & $\begin{array}{c}\text { Negative } \\
\text { results }\end{array}$ \\
\hline Plasmodium vivax & 60 & 2 & 0 & 2 & 64 \\
Plasmodium falciparum & 1 & 20 & 0 & 2 & 23 \\
Mixed infection & 0 & 0 & 0 & 0 & 0 \\
Negative results & 4 & 5 & 0 & 199 & 208 \\
Total & 65 & 27 & 0 & 203 & 295 \\
\hline
\end{tabular}

Table 5. Sensitivity of each diagnostic method according to parasitemia.

\begin{tabular}{|c|c|c|c|c|}
\hline Parasitemia & $\begin{array}{l}\text { True- } \\
\text { positive }\end{array}$ & $\begin{array}{c}\text { False- } \\
\text { negative }\end{array}$ & Total & $\begin{array}{l}\text { Diagnostic } \\
\text { agreement }\end{array}$ \\
\hline \multicolumn{5}{|l|}{ Microscopy } \\
\hline$>5000$ parasites $/ \mu \mathrm{L}$ & 68 & 0 & 68 & 100 \\
\hline $500-5000$ parasites $/ \mu \mathrm{L}$ & 17 & 2 & 19 & 89.5 \\
\hline $50-500$ parasites $/ \mu \mathrm{L}$ & 3 & 4 & 7 & 42.9 \\
\hline \multicolumn{5}{|l|}{ OptiMAL } \\
\hline$>5000$ parasites $/ \mu \mathrm{L}$ & 63 & 5 & 68 & 92.7 \\
\hline $500-5000$ parasites $/ \mu \mathrm{L}$ & 14 & 5 & 19 & 73.7 \\
\hline 50-500 parasites $/ \mu \mathrm{L}$ & 3 & 4 & 7 & 42.9 \\
\hline \multicolumn{5}{|l|}{ PCR } \\
\hline$>5000$ parasites $/ \mu \mathrm{L}$ & 67 & 1 & 68 & 98.5 \\
\hline $500-5000$ parasites $/ \mu \mathrm{L}$ & 18 & 1 & 19 & 94.7 \\
\hline 50-500 parasites/ $\mu \mathrm{L}$ & 7 & 0 & 7 & 100 \\
\hline
\end{tabular}

These values were calculated according to the criteria stated in the Material and Methods section. was shown to be a $P$. vivax false-negative result by PCR. Similarly, four samples found to be positive for $P$. falciparum by OptiMAL, failed to be diagnosed by PCR. Three of these were found to be negative when retested by PCR and OptiMAL, and one was the true-positive not detected by PCR discussed above. Additionally, three samples which originally tested positive for $P$. vivax and one that tested positive for $P$. falciparum were retested by OptiMAL and PCR and found to be positive for $P$. falciparum and $P$. vivax, respectively (species misdiagnosis), agreeing with the original PCR and microscopic results. Finally, 5 samples infected with $P$. vivax and 4 with $P$. falciparum were diagnosed as negative by OptiMAL. Retesting of these samples agreed with the original PCR and microscopic results. Mixed infection with $P$. vivax/P. falciparum was detected as a $P$. vivax infection by OptiMAL and as a $P$. falciparum infection by microscopy. The results for the 28 (9.5\%) samples with disagreement in the diagnosis by any method were concordant after retesting.

When comparing the OptiMAL and microscopic methods (Table 4), there was agreement in the diagnosis of 80 positive and 199 negative samples. Two samples were found to be positive for $P$. vivax by OptiMAL and negative by microscopy. Similarly, one sample found to be positive for $P$. falciparum by OptiMAL was diagnosed as $P$. vivax by microscopy; all three samples were species misdiagnoses by OptiMAL. Additionally, of 4 samples that were negative by microscopy 2 tested positive for $P$. vivax and 2 for $P$. falciparum, while of the 9 negative samples that tested negative by OptiMAL 4 tested positive for $P$. vivax and 5 for $P$. falciparum.

Most of the samples $(72.2 \%)$ contained more than 5000 parasites $/ \mu \mathrm{L}$ blood, while $20.2 \%$ were between $500-5000$ parasites $/ \mu \mathrm{L}$ and $7.4 \%$ showed $50-500$ parasites $/ \mu \mathrm{L}$ and none was found showing fewer than 50 parasites $/ \mu \mathrm{L}$ (Table 5). The diagnostic agreement of the microscopic examination and 
OptiMAL test decreased with lower parasitemia, but the PCR test showed the highest diagnostic agreement when samples had 50500 parasites $/ \mu \mathrm{L}$. The mixed infection showed a high number of $P$. vivax parasites (higher than 5000 parasites $/ \mu \mathrm{L}$ ) but a low number of $P$. falciparum parasites (less than 500 parasites $/ \mu \mathrm{L}$ ).

\section{Discussion}

Even though conventional microscopy is the reference method and the one most used for the diagnosis of Plasmodium spp, its sensitivity and specificity are limited to the number of tests that can be analyzed per microscopist and his/her training, especially for low-parasite densities, when more time is needed for an accurate diagnosis $(2,14)$. These limitations could explain the false results obtained in the microscopic diagnosis of the endemic populations of Sucre and Amazonas.

Zaman et al. (15) suggested that the greatest disadvantage of the microscopic diagnosis is the possibility of misdiagnosis of Plasmodium species, particularly for low parasitemia, mixed infections and when only ring forms are seen. Postigo et al. (16) reported that false-negative results by microscopy for $P$. vivax are probably due to very low parasitemia which is very difficult to detect by routine microscopic methods. This agrees with the present study, where most of the false-negative results were obtained for parasitemia lower than 500 parasites $/ \mu \mathrm{L}$.

The significantly lower sensitivity of the OptiMAL test agrees with many reports from Afghanistan, Turkey, Kuwait, Honduras, and Peru (17-21) in which the test showed sensitivities ranging from 79.3 to $94 \%$ but specificities ranging from 97 to $100 \%$. Other studies from Thailand, USA, Honduras and Colombia (22-25) have shown sensitivities and specificities close to $100 \%$, while one study from Canada (26) showed a sensitivity of 29.1 but a specificity of $95.6 \%$.
In addition, the lower sensitivity found for $P$. falciparum antigens detected by the antibodies used on the OptiMAL strips, in this study, agrees with previous reports (17, $18,20,24)$ with $6-57 \%$ differences in sensitivity but with specificities similar to those found in our study. Moody (4), in a large study with 636 patients with malaria symptoms from Sub-Saharan Africa, showed sensitivities for the OptiMAL test of 96, 95.3, 57 and $47 \%$ for $P$. vivax, P. falciparum, $P$. ovale, and $P$. malariae, respectively, and specificities of $100 \%$ for $P$. falciparum and 94\% for the other species, when compared with the microscopic diagnosis. They suggested that the lower sensitivity of the tests for $P$. falciparum infections were due to the fact that only gametocytes at low densities were present.

Miller et al. (27), evaluating the treatment of malaria by OptiMAL and conventional microscopy in 12 patients from Thailand infected with $P$. falciparum without clinical complications, found that the color intensity in the reactive strips for the OptiMAL test decreased with the levels of parasitemia, also showing that sensitivity was $88 \%$ when the density of gametes was $\geq 100 / \mu \mathrm{L}$ and $35 \%$ for densities of $<100 / \mu \mathrm{L}$. This agrees with our results regarding parasitemia and the sensitivity of OptiMAL. However, even at high parasitemia $(>5000$ parasites $/ \mu \mathrm{L}$ ), 5 false-negative results were reported for this test, which showed lower sensitivities than the other two methods at any parasitemia level.

The OptiMAL test shows sensitivity similar to those reported for other dipsticks, such as ParaSight and ICT Malaria $\mathrm{Pf} / \mathrm{Pv}$, which ranged from $86-100$ and $58-96 \%$, respectively (3,20,28-33). Iqbal et al. (20) compared the OptiMAL and ICT Malaria Pf/Pv tests, showing that OptiMAL had a higher sensitivity for the diagnosis of $P$. vivax $(79 \%)$ and $P$. falciparum (87\%), than ICT Malaria $\mathrm{Pf} / \mathrm{Pv}$ (58 and $81 \%$ respectively), but with both tests showing specificities higher than 
97\%. On the other hand, Grobusch et al. (34), comparing the ParaSight, ICT Malaria $\mathrm{Pf} / \mathrm{Pv}$ and OptiMAL tests, found similarly high sensitivities for the first two (95.1 and $95.7 \%$, respectively) and significantly lower sensitivity for OptiMAL (76.2\%), although all tests showed again specificities higher than $97 \%$.

Coleman et al. (35) evaluated the efficacy of the ICT Malaria $\mathrm{Pf} / \mathrm{Pv}$ in a large study of 559 asymptomatic patients from an endemic area of Thailand using conventional microscopy as the reference method, and found that the sensitivity for $P$. falciparum dropped from 100 to $23.3 \%$ when the parasitemia was below 500 trophozoites $/ \mu \mathrm{L}$. For $P$. vivax infections, the sensitivity dropped from $66.7 \%$ to 0 at parasitemia below 500 trophozoites $/ \mu \mathrm{L}$. In our case, diagnostic agreement for OptiMAL, was similar for both species but also dropped drastically in samples with $<500$ parasites $/ \mu \mathrm{L}$.

Our results allow us to recommend the use of both microscopy and PCR for the characterization of any diagnostic test, since by using both techniques we can obtain $100 \%$ certainty of the results. It is especially important to use PCR for the species-specific diagnosis to evaluate the treatment of malaria, since resistance to the drugs used is species-specific, so that the treatment of one type of malaria will probably not cure the other (14).

We recommend the use of PCR for the accurate diagnosis of infections in popula- tion-based studies that will allow the establishment of better relationships among the epidemiological factors that can affect the endemicity of malaria. In addition, the use of PCR-based techniques is most valuable for the evaluation of drug treatments as well as for diagnosing the emergence of drug resistance in specific areas. Thus, we recommend the incorporation of the PCR technique into the Reference Centers of government institutions responsible for malaria control, the evaluation of diagnostic tests, the verification of the quality of the microscopic diagnosis at each diagnostic center, as well as the monitoring of the emergence of resistant strains of Plasmodium parasites.

\section{Acknowledgments}

The authors wish to acknowledge to Gerencia de Saneamiento Ambiental y Malariología, Region XI, Carupano, Venezuela who donated the OptiMAL kits, as well as Isaurea Quijada (IIBCA, Universidad de Oriente, Cumana, Venezuela) and Melcenia Moreno (Instituto de Biomedicina, Ministerio de Ciencia, Tecnologia e Innovacion, Caracas, Venezuela) who helped at various stages in the research. We also wish to thank Dr. Frances Osborn for revising and correcting the English text. Finally, we wish to thank Elier Diaz (IIBCA, Universidad de Oriente, Cumana, Venezuela), who has been of great assistance in this study, working beyond the call of duty in order to complete the mission.

\section{References}

1. Dirección de Vigilancia Epidemiologica, MSDS, Venezuela. Epidemiological Bulletin, year 54 (2005), epidemiological week 52, period from 12-26 to 1-01. www.msds.gov.ve. Accessed January 12, 2005.

2. Snounou G, Viriyakosol S, Jarra W, Thaithong S, Brown KN. Identification of the four human malaria parasite species in field samples by the polymerase chain reaction and detection of a high prevalence of mixed infections. Mol Biochem Parasitol 1993; 58: 283-292.

3. Shiff CJ, Premji Z, Minjas JN. The rapid manual ParaSight-F test. A new diagnostic tool for Plasmodium falciparum infection. Trans $R$
Soc Trop Med Hyg 1993; 87: 646-648.

4. Moody A. Rapid diagnostic tests for malaria parasites. Clin Microbiol Rev 2002; 15: 66-78.

5. Makler MT, Palmer CJ, Ager AL. A review of practical techniques for the diagnosis of malaria. Ann Trop Med Parasitol 1998; 92: 419-433.

6. Piper R, Lebras J, Wentworth L, Hunt-Cooke A, Houze S, Chiodini $\mathrm{P}$, et al. Immunocapture diagnostic assays for malaria using Plasmodium lactate dehydrogenase (pLDH). Am J Trop Med Hyg 1999; 60: 109-118. 
7. Black J, Hommel M, Snounou G, Pinder M. Mixed infections with Plasmodium falciparum and $P$. malariae and fever in malaria. Lancet 1994; 343: 1095.

8. Singh B, Cox-Singh J, Miller AO, Abdullah MS, Snounou G, Rahman HA. Detection of malaria in Malaysia by nested polymerase chain reaction amplification of dried blood spots on filter papers. Trans $R$ Soc Trop Med Hyg 1996; 90: 519-521.

9. Mercereau-Puijalon O, Fandeur T, Bonnefoy $S$, Jacquemot $C$, Sarthou JL. A study of the genomic diversity of Plasmodium falciparum in Senegal. 2. Typing by the use of the polymerase chain reaction. Acta Trop 1991; 49: 293-304.

10. Roper C, Elhassan IM, Hviid L, Giha H, Richardson W, Babiker H, et al. Detection of very low level Plasmodium falciparum infections using the nested polymerase chain reaction and a reassessment of the epidemiology of unstable malaria in Sudan. Am J Trop Med Hyg 1996; 54: 325-331.

11. Farnert A, Arez AP, Correia AT, Bjorkman A, Snounou G, do Rosario $V$. Sampling and storage of blood and the detection of malaria parasites by polymerase chain reaction. Trans $R$ Soc Trop Med Hyg 1999; 93: 50-53.

12. Pouillot R, Gerbier G, Gardner IA. "TAGS", a program for the evaluation of test accuracy in the absence of a gold standard. Prev Vet Med 2002; 53: 67-81.

13. Cortese JF, Caraballo A, Contreras CE, Plowe CV. Origin and dissemination of Plasmodium falciparum drug-resistance mutations in South America. J Infect Dis 2002; 186: 999-1006.

14. McManus DP, Bowles J. Molecular genetic approaches to parasite identification: their value in diagnostic parasitology and systematics. Int J Parasitol 1996; 26: 687-704.

15. Zaman S, Tan L, Chan HH, Aziz L, Abdul-Samat S, Wahid R, et al. The detection of Plasmodium falciparum and $P$. vivax in DNAextracted blood samples using polymerase chain reaction. Trans $R$ Soc Trop Med Hyg 2001; 95: 391-397.

16. Postigo M, Mendoza-Leon A, Perez HA. Malaria diagnosis by the polymerase chain reaction: a field study in south-eastern Venezuela. Trans R Soc Trop Med Hyg 1998; 92: 509-511.

17. Kolaczinski J, Mohammed N, Ali I, Ali M, Khan N, Ezard N, et al. Comparison of the OptiMAL rapid antigen test with field microscopy for the detection of Plasmodium vivax and $P$. falciparum: considerations for the application of the rapid test in Afghanistan. Ann Trop Med Parasitol 2004; 98: 15-20.

18. Palmer CJ, Lindo JF, Klaskala WI, Quesada JA, Kaminsky R, Baum $\mathrm{MK}$, et al. Evaluation of the OptiMAL test for rapid diagnosis of Plasmodium vivax and Plasmodium falciparum malaria. J Clin Microbiol 1998; 36: 203-206.

19. Aslan G, Ulukanligil M, Seyrek A, Erel O. Diagnostic performance characteristics of rapid dipstick test for Plasmodium vivax malaria. Mem Inst Oswaldo Cruz 2001; 96: 683-686.

20. Iqbal J, Khalid N, Hira PR. Comparison of two commercial assays with expert microscopy for confirmation of symptomatically diagnosed malaria. J Clin Microbiol 2002; 40: 4675-4678.

21. Soto TA, Solari ZL, Mendoza RD, Llanos-Cuentas A, Magill A. Evaluation of the rapid diagnostic test OptiMAL for diagnosis of malaria due to Plasmodium vivax. Braz J Infect Dis 2004; 8: 151155.
22. Zakeri S, Najafabadi ST, Zare A, Djadid ND. Detection of malaria parasites by nested PCR in south-eastern Iran: evidence of highly mixed infections in Chahbahar district. Malar J 2002; 1: 2.

23. Quintana M, Piper R, Boling HL, Makler M, Sherman C, Gill E, et al. Malaria diagnosis by dipstick assay in a Honduran population with coendemic Plasmodium falciparum and Plasmodium vivax. Am J Trop Med Hyg 1998; 59: 868-871.

24. Ferro BE, Gonzalez IJ, Carvajal F, Palma GI, Saravia NG. Performance of OptiMAL(R) in the diagnosis of Plasmodium vivax and Plasmodium falciparum infections in a malaria referral center in Colombia. Mem Inst Oswaldo Cruz 2002; 97: 731-735.

25. Bualombai P, Prajakwong S, Aussawatheerakul N, Congpoung K, Sudathip S, Thimasarn K, et al. Determining cost-effectiveness and cost component of three malaria diagnostic models being used in remote non-microscope areas. Southeast Asian J Trop Med Public Health 2003; 34: 322-333.

26. Ndao M, Bandyayera E, Kokoskin E, Gyorkos TW, MacLean JD, Ward BJ. Comparison of blood smear, antigen detection, and nested-PCR methods for screening refugees from regions where malaria is endemic after a malaria outbreak in Quebec, Canada. $J$ Clin Microbiol 2004; 42: 2694-2700.

27. Miller RS, McDaniel P, Wongsrichanalai C. Following the course of malaria treatment by detecting parasite lactate dehydrogenase enzyme. Br J Haematol 2001; 113: 558-559.

28. Caraballo A, Ache A. The evaluation of a dipstick test for Plasmodium falciparum in mining areas of Venezuela. Am J Trop Med Hyg 1996; 55: 482-484.

29. Verle P, Binh LN, Lieu TT, Yen PT, Coosemans M. ParaSight-F test to diagnose malaria in hypo-endemic and epidemic prone regions of Vietnam. Trop Med Int Health 1996; 1: 794-796.

30. Singh N, Singh MP, Sharma VP. The use of a dipstick antigencapture assay for the diagnosis of Plasmodium falciparum infection in a remote forested area of central India. Am J Trop Med Hyg 1997; 56: 188-191.

31. Humar A, Ohrt C, Harrington MA, Pillai D, Kain KC. Parasight F test compared with the polymerase chain reaction and microscopy for the diagnosis of Plasmodium falciparum malaria in travelers. Am J Trop Med Hyg 1997; 56: 44-48.

32. Figueiredo Filho AF, Figueredo MC, Nascimento JM, Calvosa VS, Povoa MM, Machado RL. Performance of an immunochromatography test for vivax malaria in the Amazon region, Brazil. Rev Saúde Pública 2003; 37: 390-392.

33. Iqbal J, Muneer A, Khalid N, Ahmed MA. Performance of the OptiMAL test for malaria diagnosis among suspected malaria patients at the rural health centers. Am J Trop Med Hyg 2003; 68: 624628.

34. Grobusch MP, Hanscheid T, Gobels K, Slevogt H, Zoller T, Rogler $\mathrm{G}$, et al. Comparison of three antigen detection tests for diagnosis and follow-up of falciparum malaria in travellers returning to Berlin, Germany. Parasitol Res 2003; 89: 354-357.

35. Coleman RE, Maneechai N, Rachapaew N, Kumpitak C, Soyseng $\mathrm{V}$, Miller RS, et al. Field evaluation of the ICT Malaria Pf/Pv immunochromatographic test for the detection of asymptomatic malaria in a Plasmodium falciparum/vivax endemic area in Thailand. Am J Trop Med Hyg 2002; 66: 379-383. 